\title{
Native parasite affecting an introduced host in aquaculture: cardiac henneguyosis in the red seabream Pagrus major Temminck \& Schlegel (Perciformes: Sparidae) caused by Henneguya aegea n. sp. (Myxosporea: Myxobolidae)
}

\author{
Pantelis Katharios ${ }^{1 *} \mathbb{D}$, Panos Varvarigos², Kleoniki Keklikoglou' ${ }^{1}$, Maja Ruetten³, Jerry Sojan 1,4,5,
} Morgina Akter ${ }^{1,4,5}$, Maria Chiara Cascarano ${ }^{1}$, Maria Ioanna Tsertou ${ }^{1}$ and Constantina Kokkari ${ }^{1}$

\begin{abstract}
Background: Henneguya Thélohan, 1892 (Myxobolidae) is one of the most species-rich genera of myxosporean parasites infecting fish. Although common in nature, there are few reports of these parasites causing important disease in aquaculture. In this paper, we describe a new species of Henneguya infecting Pagrus major (Temminck \& Schlegel), a fish host introduced to the Mediterranean Sea from Japan in the late 1980s.

Results: Large plasmodia of the parasite were found in the bulbus arteriosus and in the ventricle of the infected fish. Spores were found mainly in the kidney and heart and were accompanied by melanized macrophages or vascular intimal proliferation mixed with a mild non-suppurative response, respectively. Comparisons of morphometric data for spore and polar capsule length and width, suggest a unique combination of features in the newly described species. Molecular analysis, based on 185 rDNA sequence of the parasite, followed by phylogenetic analysis, indicated that the parasite described here is a novel species of Henneguya, clustered with the marine congeneric species.

Conclusions: Henneguya aegea $\mathrm{n}$. sp. infects in aquaculture P. major, a host introduced as eggs to the Mediterranean from Japan. Despite the high host specificity of the myxobolid parasites, H. aegea n. sp. seems to be able to use $P$. major as a host and propagate successfully, causing morbidity and mortality. This could result in spillback of the new species from high density cultured non-native P. major to native fish hosts.
\end{abstract}

Keywords: Henneguya aegea n. sp., Pagrus major, Aquaculture, Exotic species, Parasite, Myxosporea

\section{Background}

Since its inception, Mediterranean marine aquaculture has been mainly reliant on the farming of two fish species, the gilthead seabream, Sparus aurata Linnaeus, and European seabass, Dicentrarchus labrax (Linnaeus).

*Correspondence: katharios@hcmr.gr

${ }^{1}$ Institute of Marine Biology, Biotechnology and Aquaculture, Hellenic Centre for Marine Research, Gournes, Heraklion, Greece

Full list of author information is available at the end of the article
Diversification, with the introduction of new species, is considered as the most appropriate way to ensure continued economic viability and sustainable growth of the industry in order to meet the increasing demand of consumers for high quality protein. Amongst the species that have long been considered as promising alternatives is the red porgy, Pagrus pagrus (Linnaeus), which is a highly valued, indigenous sparid [1]. Despite its good performance as an aquaculture species at all stages of production, the skin color of farmed red porgies darkens soon 
post-harvest while consumers expect the normal bright pink-red of the wild fish [1-3]. Thus, it was replaced in due course by the non-indigenous but morphologically similar congeneric red seabream, Pagrus major (Temminck \& Schlegel) [4]. Being exotic to the Mediterranean Sea, the red seabream showed limited, if any, pathological problems related to parasites, at least at the beginning of its rearing history, consistent with the assumption that most locally occurring parasites will be specific for local indigenous hosts. On the other hand, as it has been described for salmonids cultured in net pens in British Columbia, naïve species may contract some unusual infections when placed in a new geographical area [5]. Many of these "unusual" infections in salmonids were caused by myxosporean parasites.

Myxosporeans are microscopic metazoan parasites mainly of fish, which belong to the class of Myxosporea of the phylum Cnidaria. They can be highly host-specific and, in many cases, they show organ- or tissue tropism. Many of these parasites have been reported to be highly pathogenic resulting in debility, reduced fecundity or mortality in their fish hosts [6]. Although myxozoan parasite infections are frequently observed in Mediterranean marine aquaculture [7], very few have been associated with severe epizootics. The most important pathogen of aquaculture fish is Enteromyxum leei (Diamant, Lom \& Dykovà, 1994), which is responsible for severe losses in sparids, including the gilthead seabream, sharpsnout seabream (Diplodus puntazzo (Walbaum)) and red porgy, and unlike the majority of myxosporeans, has a wide host range $[8,9]$. Another important parasite is Sphaerospora testicularis Sitjà-Bobadilla \& Alvarez-Pellitero, 1990 which infects European seabass testes resulting in "parasitic castration" of the fish [10].

The genus Henneguya Thélohan, 1892 includes approximately 200 species described from all parts of the world, targeting mostly freshwater fish hosts and with a few also parasitic to marine fishes $[11,12]$. Henneguya spp. are histozoic myxosporeans that infect several organs of fish including the gills and the heart. In 2005, Henneguya pagri Yokoyama, Itoh \& Tanaka, 2005 was reported in red seabream farms of Japan as the causative agent of cardiac henneguyosis [13]. In the Mediterranean, Henneguya spp. have been reported in reared gilthead seabream from southern Italy, causing both morbidity and mortality [14], and from wild gilthead seabream caught off the coast of Tunis [15].

In this study, we describe a Henneguya sp. infection in cultured red seabream from the Aegean island of Leros, Greece. We suspect the parasite was acquired from local wild or cultured sparids after red seabreams were introduced to the Mediterranean, because these fish were imported as eggs from Japan in the 1980s thus precluding importation of myxosporeans from that region. We report morphological, histopathological and molecular analyses of this new parasite in an attempt to decipher its origin and possible sources of infection.

\section{Methods}

Twenty apparently healthy fish (weight: 53.7-361.7 g, total length: $15.3-25.5 \mathrm{~cm}$ ) were randomly collected in 2016 from the affected farm, which has been reporting persistent morbidity and mortality of cultured red seabream since 2010. The affected fish were reared in net pens in the sea. Usually, mortalities were in the range of $1-5 \%$ in each mortality episode and affected mostly larger fish. The fish were examined macroscopically for external and internal lesions or abnormalities. Samples from gills, kidney, liver and heart were fixed in $10 \%$ buffered formalin for routine histology. Infected hearts were dissected, and cysts of parasites were removed and fixed for electron microscopy in $2.5 \%$ glutaraldehyde in cacodylate buffer or examined fresh using a light microscope equipped with a digital camera.

\section{Spore morphology}

Henneguya spores were obtained from freshly ruptured cysts and heart scrapings from the sampled fish and measured with the aid of a light microscope equipped with an image analysis system, calibrated with a micrometric scale, following the guidelines of Lom \& Arthur [16]. Measurements were based on 55 fresh spores and are presented in micrometres as the range followed by the mean \pm standard deviation, SD.

\section{Scanning electron microscopy (SEM)}

Samples for SEM were washed with sodium cacodylate buffer, post-fixed with $1 \% \mathrm{OsO}_{4}$ and dehydrated in an ascending alcohol series, mounted on stubs, sputtercoated with gold palladium and examined using a JEOL JSM-6390LV scanning electronic microscope at $15 \mathrm{kV}$ at the Electron Microscopy Laboratory of the University of Crete.

\section{Histology}

Formalin-fixed tissues were dehydrated in a 70-96\% ethanol series and embedded in glycol methacrylate resin (Technovit 7100, Heraeus Kulzer, Germany). Serial sections (3-5 $\mu \mathrm{m}$ thick) were obtained using a microtome (Leica RM2245, Germany) with disposable blades. After drying, slides were stained with methylene blue/azure II/ basic fuchsin (Polychrome) [17]. Another set of samples was also processed for paraffin sectioning; these tissues were fixed for $72 \mathrm{~h}$ in $10 \%$ buffered formalin, dehydrated in an ascending ethanol series (70-100\%), embedded in paraffin and cut in $2-3 \mu \mathrm{m}$ thin sections. They were 
stained using a standard protocol with haematoxylin and $\operatorname{eosin}(\mathrm{H} \& \mathrm{E})$.

\section{Micro-CT}

Two infected and one uninfected heart were also examined with micro-CT. These samples were fixed in $4 \%$ phosphate-buffered formalin and dehydrated to $70 \%$ ethanol for 3 days before scanning. Subsequently, two different staining agents were used in each infected sample in order to enhance the contrast between the soft tissues. One affected and one control heart were stained with $0.3 \%$ phosphotungstic acid (PTA) in $70 \%$ ethanol while the second affected heart was stained with $1 \%$ iodine in $96 \%$ ethanol according to the protocol of Metscher [18]. The micro-CT scans of the hearts were performed at the Hellenic Centre for Marine Research (HCMR) using the SkyScan 1172 micro-CT scanner (SkyScan, Bruker, Belgium). This scanner uses a tungsten $\mathrm{X}$-ray source with an anode voltage ranging from 20 to $100 \mathrm{kV}, 11 \mathrm{MP}$ CCD camera $(4000 \times 2672$ pixel $)$ and a maximal resolution of $<0.8 \mu \mathrm{m} /$ pixel. The hearts \#1 and the healthy control were scanned at a voltage of $67 \mathrm{kV}$ and $150 \mu \mathrm{A}$, while the heart \#2 was scanned at a voltage of $80 \mathrm{kV}$ and $124 \mu \mathrm{A}$. All scans were performed with an aluminum filter for a full rotation of $360^{\circ}$ at the highest camera resolution. The projection images acquired during the scanning procedure were reconstructed into cross-section images using the SkyScan's NRecon software (NRecon, Skyscan, Bruker, Belgium) which implements a modified Feldkamp's back-projection algorithm. Furthermore, 3D volume renderings of the scanned specimen were created using the CTVox software (CTVox, Skyscan, Bruker, Belgium) to visually investigate the anatomy of the internal and external 3D structures of the sample.

\section{DNA isolation and sequencing}

Infected arterial bulbs preserved in 95\% ethanol were used for DNA extraction. Samples were centrifuged at $8000 \times g$ for $10 \mathrm{~min}$ and the ethanol supernatant was removed. DNA was extracted from the dried pellet using QIAgen DNeasy kit (Qiagen, Valencia, California, USA) according to manufacturer's instructions. Small subunit ribosomal DNA (SSU rDNA) was amplified by the polymerase chain reaction (PCR) technique using Taq PCR Master Mix kit (Qiagen) and the primers MyxospecF (5'-TTC TGC CGT ATC AAC TWG TTG-3') [19] and 18R (5'-CTA CGG AAA CCT TGT TAC G-3') [20]. PCR reactions were performed in a BIO-RAD MJ Mini Personal Thermal Cycler with an initial denaturation at $94{ }^{\circ} \mathrm{C}$ for $3 \mathrm{~min}$, followed by 35 cycles of denaturation at $94{ }^{\circ} \mathrm{C}$ for $1 \mathrm{~min}$, annealing at $56{ }^{\circ} \mathrm{C}$ for $1 \mathrm{~min}$ and extension at $72{ }^{\circ} \mathrm{C}$ for $90 \mathrm{~s}$ and a final extension step at $72{ }^{\circ} \mathrm{C}$ for 5 min. PCR products were visualized in an ethidium bromide-stained 1\% agarose gel and then purified with PURELINK PCR purification kit (Invitrogen - Thermo Fisher Scientific Inc, Waltham MA, USA). PCR products were sequenced using ABI3730xl sequencer (Applied Biosystems) according to the protocol BigDye Terminators 3.1 (Applied Biosystems, ThermoFisher Scientific Inc, Waltham MA, USA).

\section{Phylogenetic analysis}

All available $S S U$ rDNA sequences of Henneguya species infecting fish were downloaded from GenBank and used in the present study; Ceratomyxa diplodae Lubat, Radujkovic, Marques \& Bouix, 1989 (KX099691.1) was used as the outgroup. The novel sequences were edited by eye, trimmed to 1830 bp with Geneious 9.1 and aligned with the GenBank sequences using ClustalW in Geneious 9.1 with default settings. Phylogenetic analysis was done by Neighbour-Joining method in MEGA 7 [21] using Tamura-Nei model and pairwise deletion option. Genetic distances were calculated using MEGA 7 and the "compute pairwise distances" option of the Tamura-Nei model.

\section{Results \\ Gross pathology}

Sporadic incidents of diagnosed red sea bream henneguyosis from Leros Island date back to 2010. In these cases, either persisting low morbidity and daily mortality $(\leq 1 \%)$, or sudden deaths of apparently healthy-looking fish were reported with occasional minor superficial skin lesions. Mortality was low and not associated with a particular size range of fish or season of year but was of concern to the farmers when large marketable fish were lost or when candidate broodstock fish under quarantine were affected. Most of the fish examined ( 90\%) appeared normal externally with no hemorrhages on skin or erosion of fins, but sometimes the skin was dull with superficial inflammation, minor erosions and scale loss. Gills were moderately inflamed with excessive mucus secretions.

At gross examination, infected hearts had enlarged arterial bulbs as well as obvious areas of myocardium degeneration (Figs. 1a, b, 2a). When dissected, these hearts revealed numerous large, white to cream-colored, 1 to $2 \mathrm{~mm}$ in diameter, irregularly shaped plasmodia in the ventricle (Fig. 2b) containing large numbers of developing Henneguya sp. spores (Fig. 2c). Abundant free mature spores were found in microscopic examination of the atrium and bulbus arteriosus (Fig. 2d). Spores were apparently disseminated via blood circulation to all body parts and organs. Numerous mature spores were found in the kidney, eliciting a host response characterized by proliferation of the melanomacrophage centers (Fig. 2e). 

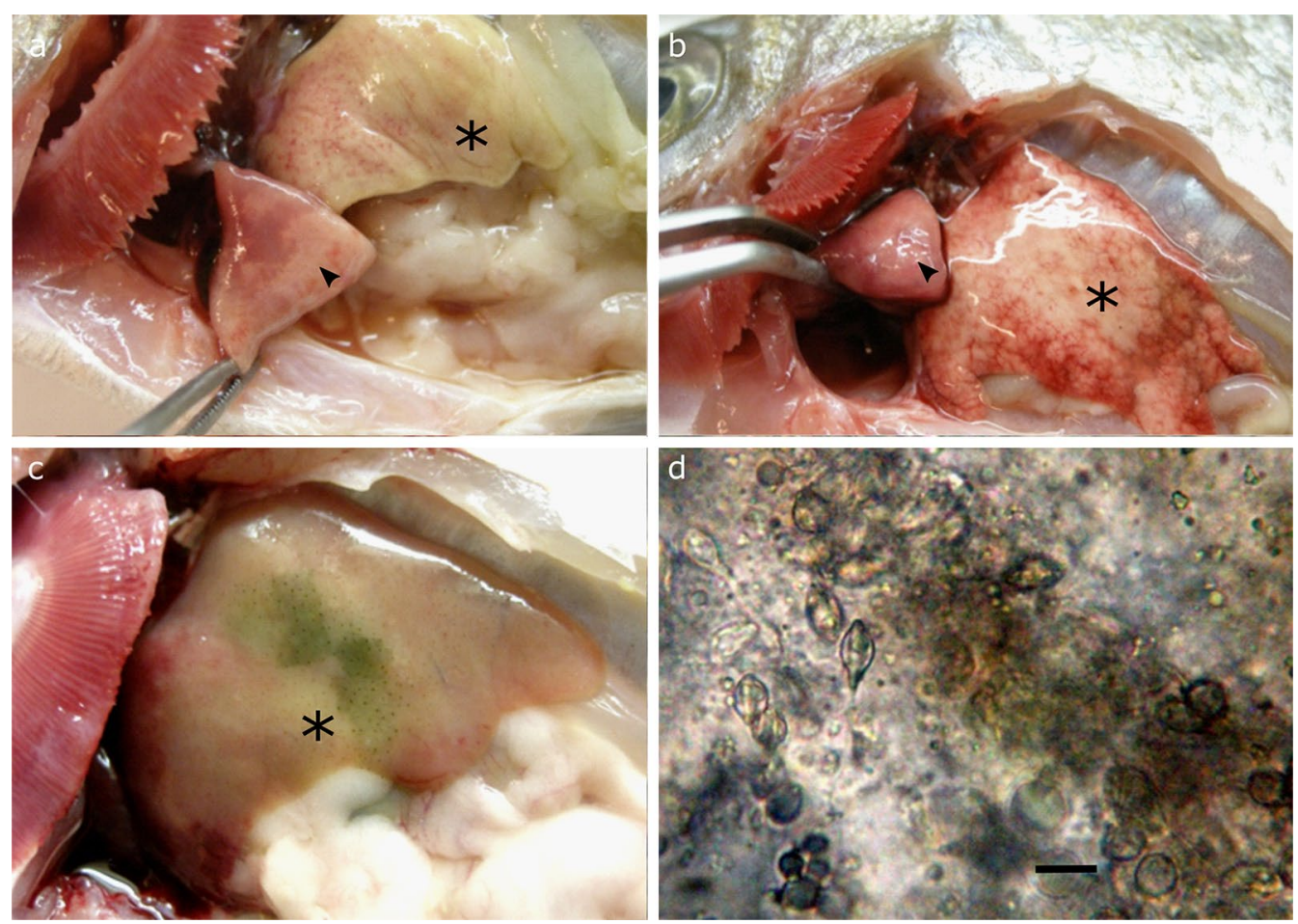

Fig. 1 a, b Infected hearts (arrowheads) with noticeable myocardium degeneration. Haemorrhagic and degenerated livers (asterisks) (a and $\mathbf{b})$ with bile imbibition (c). d Mature spores of Henneguya aegea n. sp. in fresh liver tissue squash under light microscopy (magnification $\times 400)$. Scale-bar: $\mathbf{d}$, $10 \mu \mathrm{m}$

Examination of the macrophage aggregations in fresh squash preparations of the kidney by light microscopy at higher magnification revealed that they encompassed free parasitic spores (Fig. 2f). A few spores were also present in the ventricle, gills, digestive mucosa, liver parenchyma (Fig. 1d) and gall-bladder wall.

Livers at necropsy appeared swollen and pale due to vacuolar hepatic lipidosis, sometimes with petechial hemorrhages and areas with a greenish tinge apparently due to post-mortem bile imbibition (Fig. 1a-c). Cohesive hepatic parenchyma (squash) observed under the microscope showed diffuse fatty degeneration (vacuolar hepatopathy) and an abundance of Henneguya spores (Fig. 1d).

\section{Histopathology}

Multiple cysts (plasmodia) of the myxozoan parasite with a broad eosinophilic, hyaline cyst walls measuring $10 \mu \mathrm{m}$ in thickness were observed in the lumen of the ventricle and bulbus arteriosus of the infected hearts (Fig. 3a, b, d). Within the cysts, numerous developing spores were visible (Fig. 3a, c). Several ellipsoid clear areas directed towards the arterial lumen of the bulbus were observed in the cyst wall; these were previously described as pinocytotic channels [22]. The cysts observed were often closely aligned to the endothelium but without real attachment. The endothelium of the endocardium and numerous large vessels showed papilliform proliferations into the vessel lumens consisting of the endothelial cells (Fig. 3e). Within the myocardium, there were only very small foci of degeneration consisting of loss of the myofibers and slight infiltrations of macrophages and lymphocytes. Similar proliferations of the intima of larger blood vessels were also present especially in the spleen and liver. Here, the lumens of the vessels were almost completely obstructed by the intima proliferations (arteriosclerosis). This lesion was characterized more by proliferative and degenerative changes than inflammation within the vessel wall. Few inflammatory cells were intermingled within the proliferations (Fig. 3f). Gills were mostly normal with very mild fusion of some secondary lamellae with focal lymphocytes and histiocytic infiltrates.

\section{Micro-CT}

In the first sample (heart \#1), the micro-CT scans revealed numerous large plasmodia located in the ventricle (Fig. $4 \mathrm{a}-\mathrm{c}$ ). A membrane surrounding the plasmodia was visible in the images. In this sample, no plasmodia were found in the bulbus arteriosus. In the second sample (heart \#2), three large plasmodia were 

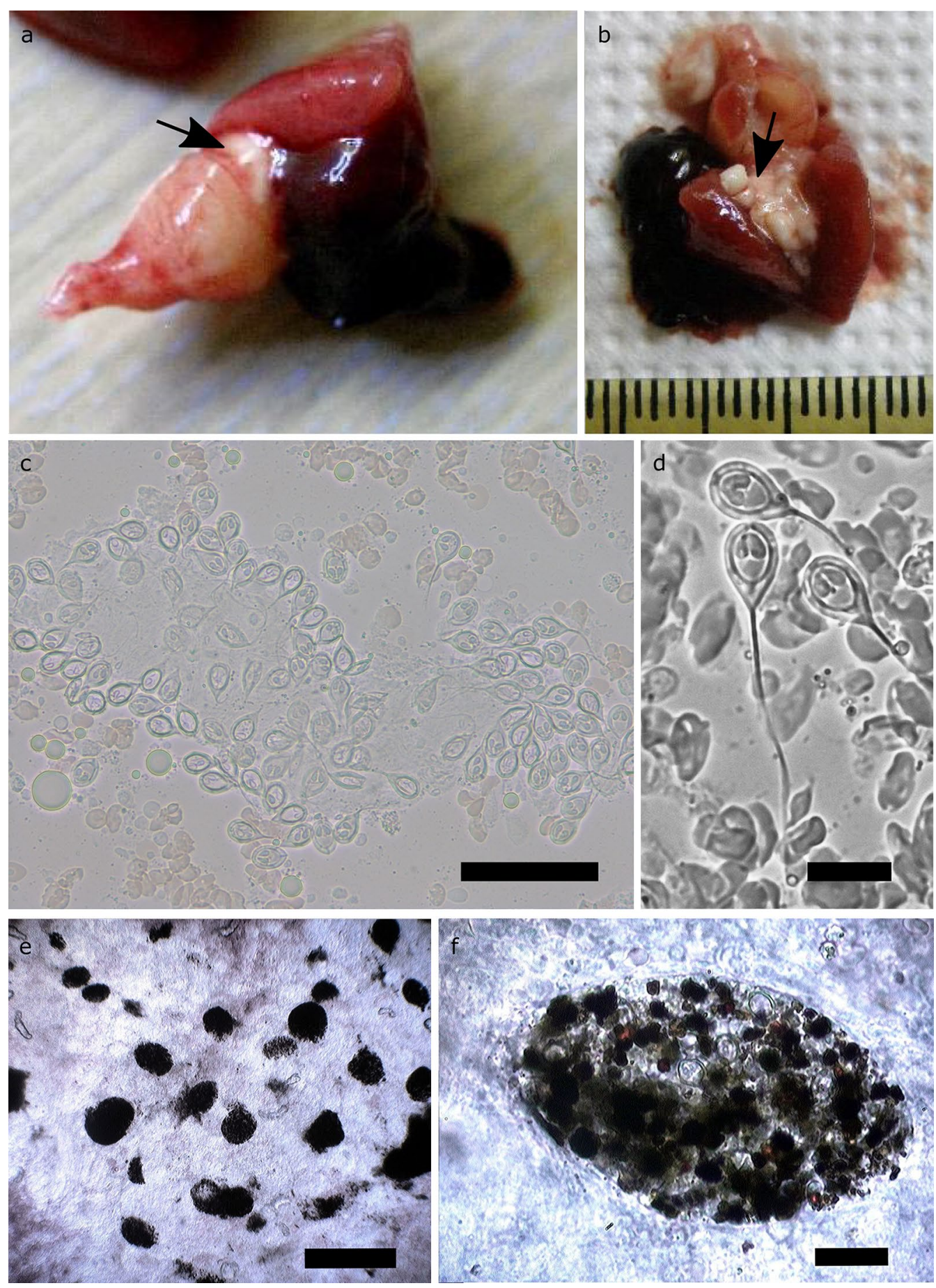

Fig. 2 a Infected heart with distended bulbus arteriosus; note the plasmodium (arrow) at the basis of bulbus arteriosus. b Numerous large white plasmodia inside the ventricle (arrow) containing large numbers of myxosporean spores. c Developing spores of Henneguya aegea $\mathrm{n}$. sp. from a ruptured plasmodium under light microscopy. $\mathbf{d}$ Light microscopy of unstained mature H. aegea n. sp. (magnification $\times 400$ ) (under phase contrast). e Proliferation of melanomacrophage centers in Henneguya-infected kidney (squash mount). $\mathbf{f}$ Higher magnification of the macrophage accumulation with H. aegea n. sp. spores. Scale-bars: c, $50 \mu \mathrm{m} ; \mathbf{d}, 10 \mu \mathrm{m} ; \mathbf{e}, 20 \mu \mathrm{m} ; \mathbf{f}, 20 \mu \mathrm{m}$ 


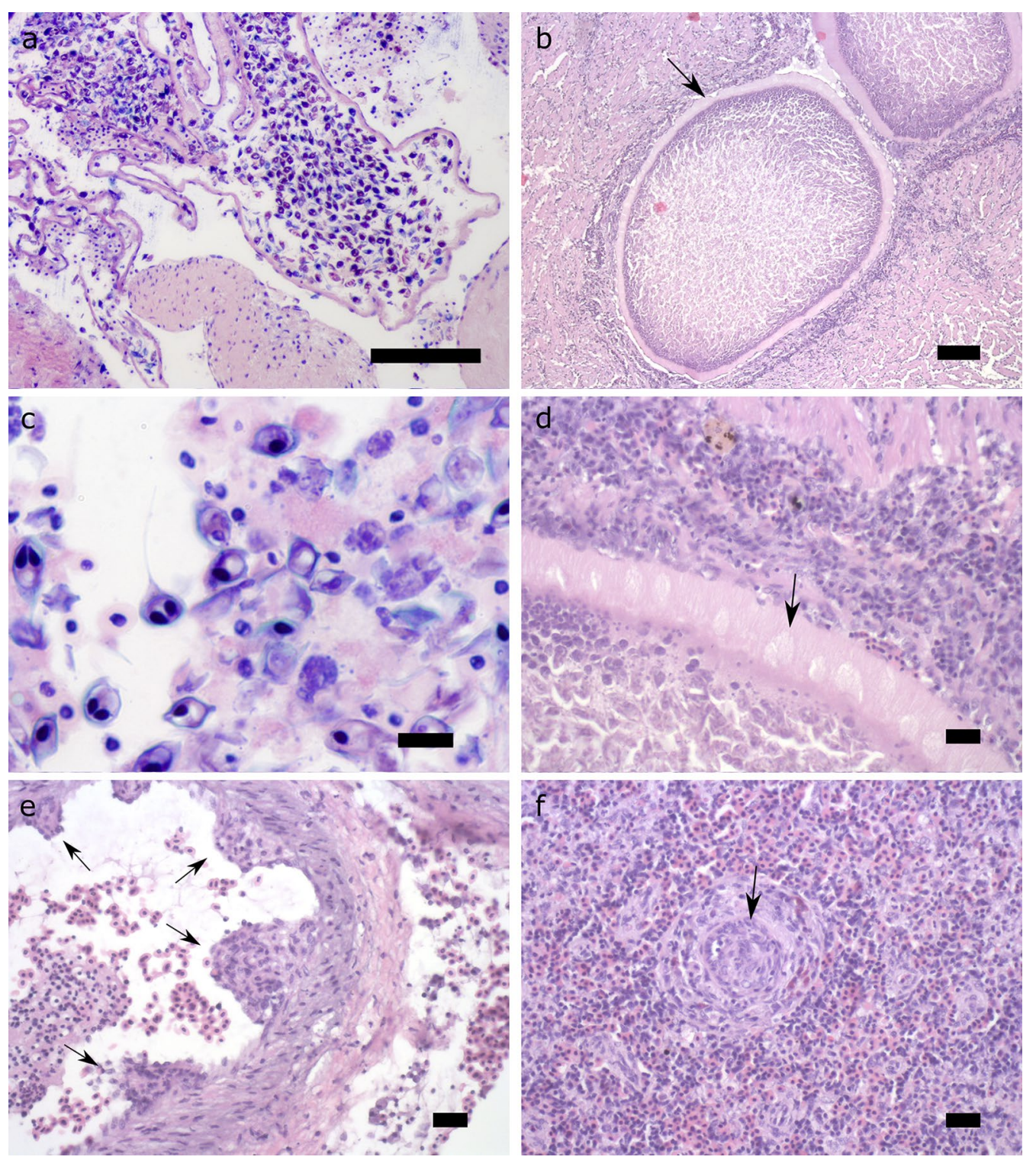

Fig. 3 a Developed plasmodium containing a large number of developing spores in the bulbus arteriosus of the affected fish (Resin embedded tissue; methylene blue/azure II/basic fuchsin staining). $\mathbf{b}$ Intact plasmodia of the parasite in the bulbus arteriosus (paraffin-embedded tissue; H\&E staining) with broad eosinophilic capsule (arrow). c Developing spores of Henneguya aegea $\mathrm{n}$. sp. from the heart at higher magnification showing the dark-stained pyriform polar capsules (resin-embedded tissue; methylene blue/azure II/basic fuchsin staining). $\mathbf{d}$ Capsule of the plasmodium with ellipsoid clearer areas indicating pinocytotic channels (arrow). e Papilliform proliferated intima (arrows) of a large blood vessel wall in the heart. f Proliferation of the intima of the blood vessels in the spleen obstructing the lumen (arrow). Scale-bars: $\mathbf{a}, 100 \mu \mathrm{m} ; \mathbf{b}, 200 \mu \mathrm{m} ; \mathbf{c}, 10 \mu \mathrm{m} ; \mathbf{d}, 40 \mu \mathrm{m} ; \mathbf{e}$, $40 \mu \mathrm{m} ; \mathbf{f}, 20 \mu \mathrm{m}$

identified in the ventricle and one in the basis of the bulbus arteriosus (Fig. 4d). Following scanning, the sample was dissected in the area where the plasmodia were seen in micro-CT in order to validate the tomography findings (Fig. 4e). The plasmodia were removed, and squash preparations confirmed that these were plasmodia of the Henneguya sp. Using the CTAnalyzer software (CTAN, Skyscan, Bruker, Belgium), we measured the volume of the three plasmodia and the ventricle. The three plasmodia occupied approximately $2 \%$ of the total volume of the ventricle. A video of the scanning of the two hearts is provided in Additional file 1: Video S1. 
a
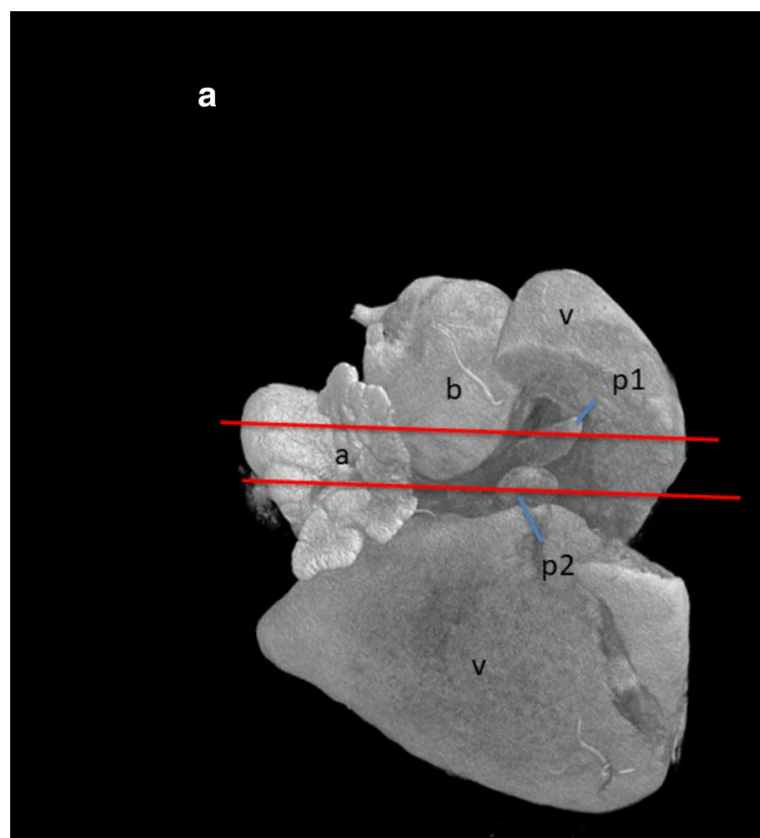

\section{b}

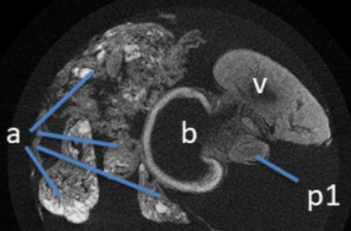

p1

c

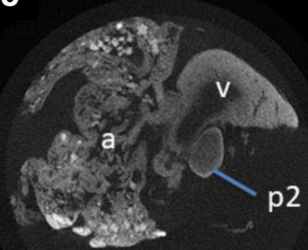

d

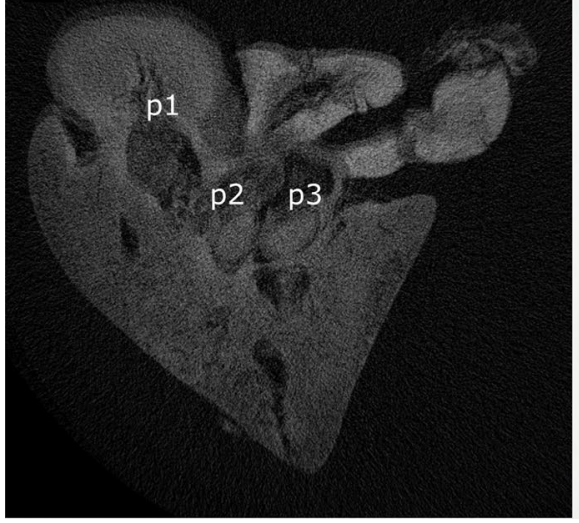

e

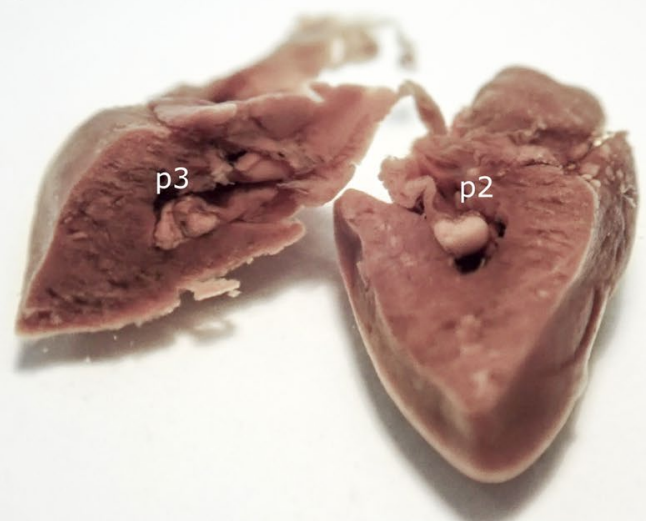

Fig. 4 Images of infected hearts using the micro-CT technology, showing the location and the appearance of the plasmodia in the ventricle. a $3 \mathrm{D}$ volume rendering of the heart \#1. Two plasmodia $(\mathrm{p} 1, \mathrm{p} 2)$ of Henneguya aegea $\mathrm{n}$. sp. are visible through a dissection cut in the ventricle. Red lines indicate the section plan of the corresponding 2D cross-section images (b and $\mathbf{c}$ ). $\mathbf{d}$ Cross-section image of the heart \#2 showing two large plasmodia in the ventricle (p2 and p3) and one in the junction of the bulbus arteriosus with the ventricle. e Heart \#2 (scanned in D) dissected in the area where the plasmodia were identified through micro-CT showing the actual location and appearance of $\mathrm{p} 2$ and p3. Abbreviations: a, atrium; b, bulbus arteriosus; $p$, plasmodium; $v$, ventricle

\section{Family Myxobolidae Thélohan, 1892}

Genus Henneguya Thélohan, 1892

\section{Henneguya aegea n. sp}

Type-host: Pagrus major (Temminck \& Schlegel) (Perciformes: Sparidae), red seabream.

Type-locality: Off Leros, Aegean Sea, Greece.
Type-material: Type (air-dried slide stained with Giemsa) is deposited in the collection of the Natural History Museum of Crete, Heraklion, Greece (accession no. NHMC60.8).

Site of infection: Heart, bulbus arteriosus and ventricle. Prevalence: 50\% (10 out of 20 fish). 
Representative DNA sequence: SSU rRNA gene, GenBank accession number MK007473.

ZooBank registration: To comply with the regulations set out in article 8.5 of the amended 2012 version of the International Code of Zoological Nomenclature (ICZN) [23], details of the new species have been submitted to ZooBank. The Life Science Identifier (LSID) of the article is urn:lsid:zoobank. org:pub:CDC0D4EF-5A29-4A0B-937D-6908E8E2570F. Etymology: Aegea (feminine) in Greek, originating from the Aegean Sea, where the fish were cultured.

\section{Description}

[Based on 55 spores. Figs. 1d, 2c, d, 3c, 5, 6a-e] Spore body oval-shaped in frontal view, with slightly attenuated posterior end elongated into 2 caudal processes (Figs. $2 \mathrm{~d}$, $5)$. Spore body length $10.0-14.9$ (12.8 \pm 1.0$)$, width $5.7-$ $10.9(8.2 \pm 1.1)$, wall thickness $5.2-7.0(6.2 \pm 0.6)$. Caudal processes 2, equal in length, 34.1-60.6 (42.6 \pm 6.5$)$. Polar capsules 2, pyriform, 1.4-6.8 (3.4 \pm 0.6$)$ in length, $0.8-2.5$ $(1.7 \pm 0.3)$ in width. Total length (spore body and processes) $53.6-82.8(64.9 \pm 8.7)$.

\section{Differential diagnosis}

A comparation of taxonomic characters with congeneric species of the genus (Table 1) does not clearly indicate significant similarity. Median length and width of the spores of $H$. aegea n. sp. resemble those reported for $H$. mauritaniensis Khlifa, Miller, Adlard, Faye \& Sasal, 2012 and the Henneguya spp. found on Pagrus major in Italy (even though no spore thickness is reported in these two species) but the new species differs in all other examined parameters. Measurements of the polar capsule are less variable between Henneguya spp. and can be seen in the newly described species as similar to the ones described in H. cynoscioni Dykova, Buron, Roumillat \& Fiala, 2011, H. akule Work, Takata, Whipps \& Kent, 2008, H. pagri, H. lateolabracis Yokoyama, Kawakami, Yasuda \& Tanaka, 2003, H. vitiensis Laird, 1950, and H. yokoyama Li, Sato, Kamata, Ohnishi \& Sugita-Konishi 2012.

Taking into account the high intraspecific size variability of parasites in the same sample and the possibility that the length of the caudal processes is no longer considered a systematic character, other infection parameters and/ or molecular data should be taken into consideration to determine species distinct status. To our knowledge, Henneguya aegea $\mathrm{n}$. sp. is the first member of the genus with plasmodia developing not only in the bulbus arteriosus but also in the ventricle (tissue tropism).

\section{Scanning electron microscopy (SEM)}

Observations with SEM showed that the spores had a smooth surface and two unequal valves which were

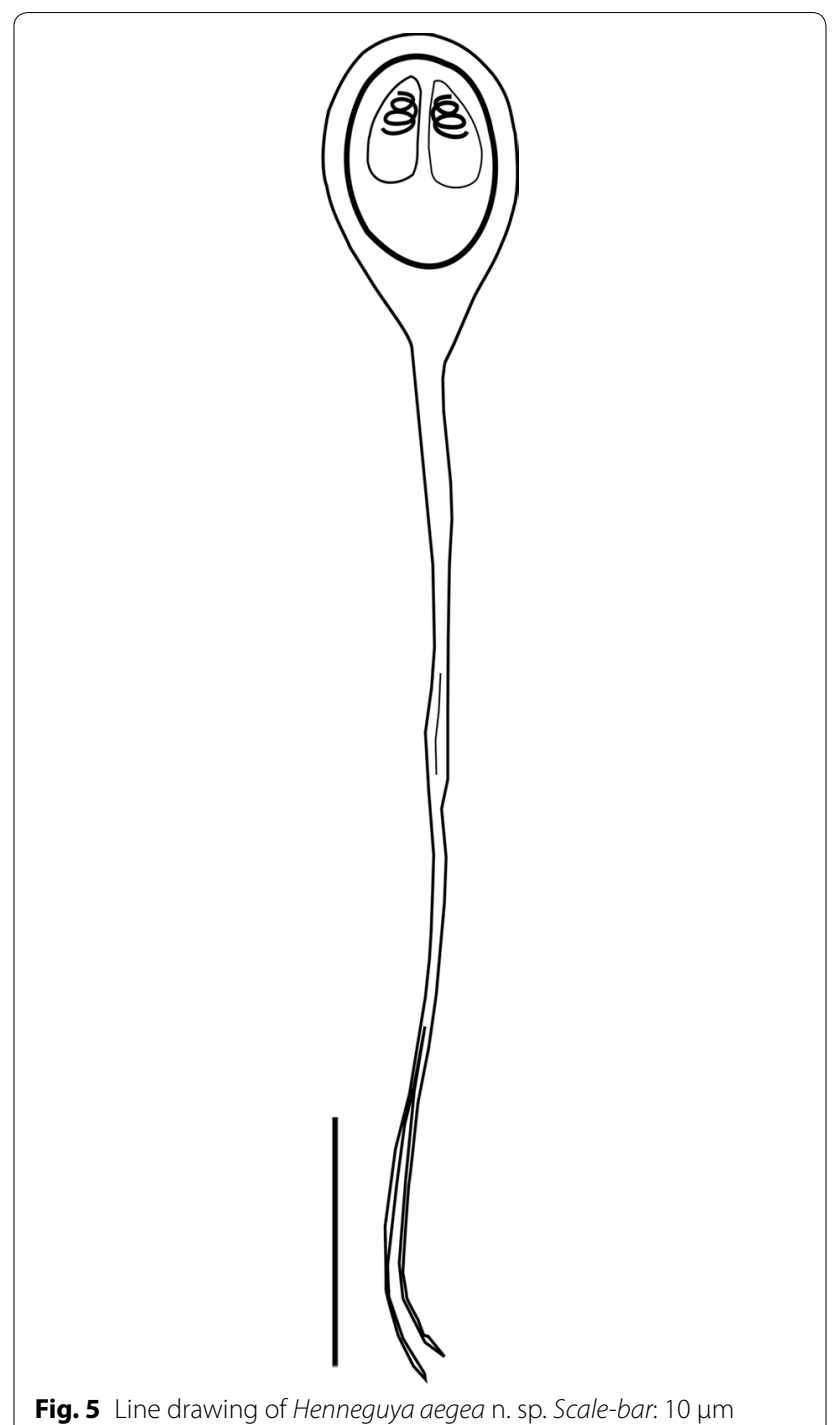

joined forming a conspicuous sutural line. At the front part of the spore, two polar tubule discharge pores were observed, each situated in either valve connected to the sutural line. The long caudal processes were separated but were in contact for at least the first half of their length (Fig. 6).

\section{Molecular analysis and phylogeny}

A small subunit rRNA (SSU rRNA) gene sequence of $1727 \mathrm{nt}$ in length was obtained from $H$. aegea n. sp. All $S S U$ rRNA gene sequences $(n=52)$ from Henneguya spp. available on GenBank (August 2018) were retrieved and aligned with $H$. aegea n. sp. sequence using ClustalW in Geneious 9.1. Following trimming which resulted in an alignment with a total of 1830 characters including alignment gaps, a phylogenetic tree using the Neighbor-Joining method with 1000 bootstraps was constructed with 

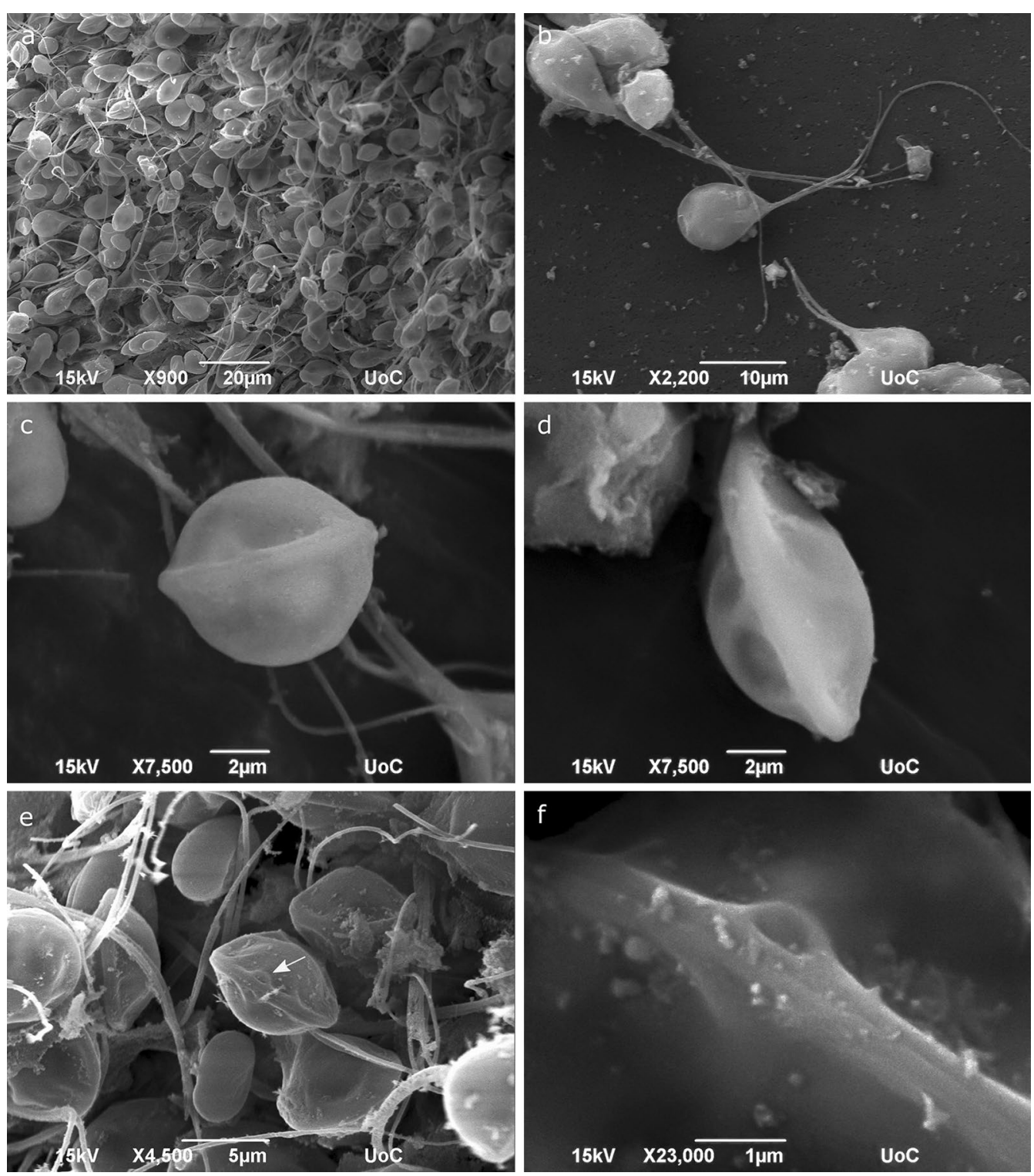

Fig. 6 SEM micrographs. a Numerous spores of Henneguya aegea n. sp. from a ruptured plasmodium. b Frontal view of the spores. c Frontal view of the spore showing the sutural line. $\mathbf{d}$ Side view of the spore. e Frontal view of the spore showing two polar tubule discharge pores (arrow) located over the sutural line at each valve. $\mathbf{f}$ Higher magnification of the polar tubule discharge pores

Ceratomyxa diplodae as the outgroup. Henneguya aegea n. sp. clustered with the other Henneguya spp. infecting marine species and formed a separate clade with $H$. cynoscioni, H. tunisiensis (Bahri, Marton, Marques \& Eszterbauer, 2010), H. pagri and H. mauritaniensis (Fig. 7). The highest similarity expressed as \% identity (\% of bases/ residues which are identical) was with $H$. mauritaniensis (89.8\%) followed by H. pagri (89.5\%).

\section{Discussion}

As marked in the differential diagnosis, the spore measurements of the new species resemble those of Henneguya sp. reported by Caffara et al. [14] in Italy, but differs in other parameters such as the length and width of the median polar capsule and the length of the caudal processes. The caudal processes of $H$. aegea n. sp. are much longer than those of Henneguya sp. found in the 
Table 1 Comparative data for Henneguya aegea n. sp. and other congeneric species

\begin{tabular}{|c|c|c|c|c|c|c|c|c|}
\hline Species & Host & Site in host & Locality & Spore $(L \times W)$ & Thickness & $\begin{array}{l}\text { Polar capsule }(\mathrm{L} \\
\times \mathrm{W})\end{array}$ & $\begin{array}{l}\text { Caudal process } \\
\text { length }\end{array}$ & Reference \\
\hline $\begin{array}{l}\text { Henneguya } \\
\text { aegea n. sp. }\end{array}$ & Pagrus major & Heart & Off Greece & $\begin{array}{c}10.0-14.8 \times \\
5.6-10.9 \\
(12.8 \times 8.1)\end{array}$ & $5.1-7.0(6.2)$ & $\begin{array}{l}1.4-6.8 \times \\
0.8-2.5(3.4 \\
\times 1.7)\end{array}$ & $34.1-60.6(42.6)$ & Present study \\
\hline H. akule & $\begin{array}{l}\text { Selarcru- } \\
\text { menophthal- } \\
\text { mus }\end{array}$ & $\begin{array}{l}\text { Bulbus arte- } \\
\text { riosus }\end{array}$ & Hawaii & $12.1 \times 7.4$ & & $3.4 \times 1.4$ & 28.7 & {$[39]$} \\
\hline H. cynoscioni & $\begin{array}{l}\text { Cynoscion } \\
\text { nebulosus }\end{array}$ & $\begin{array}{l}\text { Bulbus arte- } \\
\text { riosus }\end{array}$ & Off USA & $10.4 \times 8.8$ & & $3.3 \times 2$ & 8.1 & [22] \\
\hline H. lateolabracis & Lateolabrax sp. & $\begin{array}{l}\text { Bulbus arte- } \\
\text { riosus }\end{array}$ & Off Japan & $\begin{array}{l}9.9-11.9 \times \\
6.4-7.8(10.7 \\
\times 7.5)\end{array}$ & 5.9-6.4 (6.2) & $\begin{array}{l}3.0-4.0 \times \\
\quad 1.5-2.0(3.4 \\
\times 1.7)\end{array}$ & $30.7-49.5(37.7)$ & {$[37]$} \\
\hline $\begin{array}{l}\text { H. mauritanien- } \\
\text { sis }\end{array}$ & $\begin{array}{l}\text { Pagrus caerule- } \\
\text { ostictus }\end{array}$ & $\begin{array}{l}\text { Bulbus arte- } \\
\text { riosus }\end{array}$ & Off Mauritania & $12.3 \times 8.0$ & & $4.1 \times 3.0$ & 25.3 & [29] \\
\hline H. otolithi & $\begin{array}{l}\text { Otolithes rubber; } \\
\text { O. maculatus }\end{array}$ & $\begin{array}{l}\text { Bulbus arte- } \\
\text { riosus }\end{array}$ & Off India & $10-12 \times 6-8.5$ & $4-5$ & $\begin{array}{r}3.0-4.0 \times \\
2.0-2.5\end{array}$ & $35.0-40.0$ & {$[42]$} \\
\hline H. ogawai & $\begin{array}{l}\text { Acanthopagrus } \\
\text { schlegelii }\end{array}$ & Alimentary tract & Off Japan & $\begin{array}{l}8.9-12.2 \times \\
6.3-7.5(11.0 \\
\times 6.9)\end{array}$ & $5.2-6.6(5.9)$ & $\begin{array}{l}3.8-5.2 \times \\
1.4-2.3(4.3 \\
\times 1.9)\end{array}$ & $8.4-12.7(10.0)$ & {$[43]$} \\
\hline H. pagri & Pagrus major & $\begin{array}{l}\text { Bulbus arte- } \\
\text { riosus }\end{array}$ & Off Japan & $\begin{array}{l}9.9-11.9 \times \\
6.4-8.4(10.5 \\
\times 7.5)\end{array}$ & 5.4-6.4 (5.9) & $\begin{array}{l}2.5-4.0 \times \\
1.5-2.0 \\
(3.1 \times 1.6)\end{array}$ & $24.8-34.7(29.6)$ & [13] \\
\hline H. sebasta & $\begin{array}{l}\text { Sebastes pau- } \\
\text { cispinis }\end{array}$ & $\begin{array}{l}\text { Bulbus arte- } \\
\text { riosus }\end{array}$ & Off USA & $\begin{array}{l}13.0-17.5 \times \\
5.6-11.0(15.1 \\
\times 9.2)\end{array}$ & 5.0-8.7 (7.1) & $\begin{array}{l}3.7-5.6 \times \\
1.8-3.1(4.5 \\
\times 2.4)\end{array}$ & $32.5-87.5(62.0)$ & {$[40]$} \\
\hline H. tunisiensis & $\begin{array}{l}\text { Symphodus } \\
\text { tinca }\end{array}$ & Gill arches & OffTunisia & $13.1 \times 9.1$ & & $2.0 \times 4.0$ & 28.4 & {$[26]$} \\
\hline H. vitiensis & $\begin{array}{l}\text { Leiognathus } \\
\text { fasciatus }\end{array}$ & Heart & Off Fiji & $13.7 \times 7.8$ & & $3.2 \times 1.7$ & 29.1 & [41] \\
\hline H. yokoyamai & $\begin{array}{l}\text { Acanthopagrus } \\
\text { schlegelii }\end{array}$ & Gall-bladder & Off Japan & $\begin{array}{l}10.1-13.7 \times \\
6.6-7.5(11.0 \\
\times 7.1)\end{array}$ & $4.5-6.4(5.6)$ & $\begin{array}{l}3.1-4.2 \times \\
1.8-2.4(3.7 \\
\times 2.0)\end{array}$ & $10.8-17.0(14.1)$ & {$[43]$} \\
\hline H. zikawiensis & $\begin{array}{r}\text { Carassius } \\
\text { auratus }\end{array}$ & Heart & Off China & $\begin{array}{l}10.0-14.0 \times \\
8.0-10.0(11.4 \\
\times 8.5)\end{array}$ & 7.0-8.0 (7.3) & $\begin{array}{l}4.0-5.5 \times \\
2.5-4.0(4.7 \\
\times 3.3)\end{array}$ & & {$[44]$} \\
\hline Henneguya sp. & Sparus aurata & $\begin{array}{l}\text { Bulbus arte- } \\
\text { riosus }\end{array}$ & Off Italy & $12.9 \times 7.8$ & & $4.5 \times 2.5$ & 23.2 & [14] \\
\hline Henneguya sp. & Sparus aurata & Gills & OffTunisia & $13.4 \times 9.47$ & & $4.75 \times 2.25$ & 26.5 & {$[15]$} \\
\hline
\end{tabular}

Note: Measurements are given in $\mu \mathrm{m}$

Abbreviations: $L$, length; $W$, width

gilthead seabream and close to those in $H$. otolithi Ganapati, 1941 and H. lateolabracis. However, it has been suggested that the caudal processes of myxobolids might not be a valid taxonomic character. The fact that this character is intermixed within the phylogeny of myxobolids suggests that the genetic capacity to develop spore tails exists broadly within this family, but only certain lineages express it. The irregular occurrence of caudal processes throughout the myxozoan tree of life is emphasized further by the appearance of this trait in the spores of some species of Myxobolus Bütschli, 1882 as reported for M. turpisrotundus Zhang, 2009 [24]. The close affinity between Myxobolus and Henneguya has been revealed in both morphological and phylogenetic studies [6, 24-26].
Identification of myxosporean parasites can be greatly assisted by their tissue/organ preference since apart from being highly host-specific, many myxosporeans also show high tissue tropism [27]. The plasmodial stages of $H$. aegea $\mathrm{n}$. sp. were located in the heart tissue, in the bulbus arteriosus and the ventricle, although many of the spores were observed in the liver and few in the gills and kidney, likely as a result of dispersion of the parasite through the blood flow. Several myxosporean species have been found to infect fish hearts (Table 1); according to Ye et al. [28] the list of heart-infecting myxosporeans included ten Henneguya spp. (H. zikawiensis Sikama, 1938, H. otolithi, H. vitiensis, H. sebasta Moser \& Love, 1975, H. brachideuteri Kpatcha, Faye, Diebakate, Fall \& Toguebaye, 1997, 


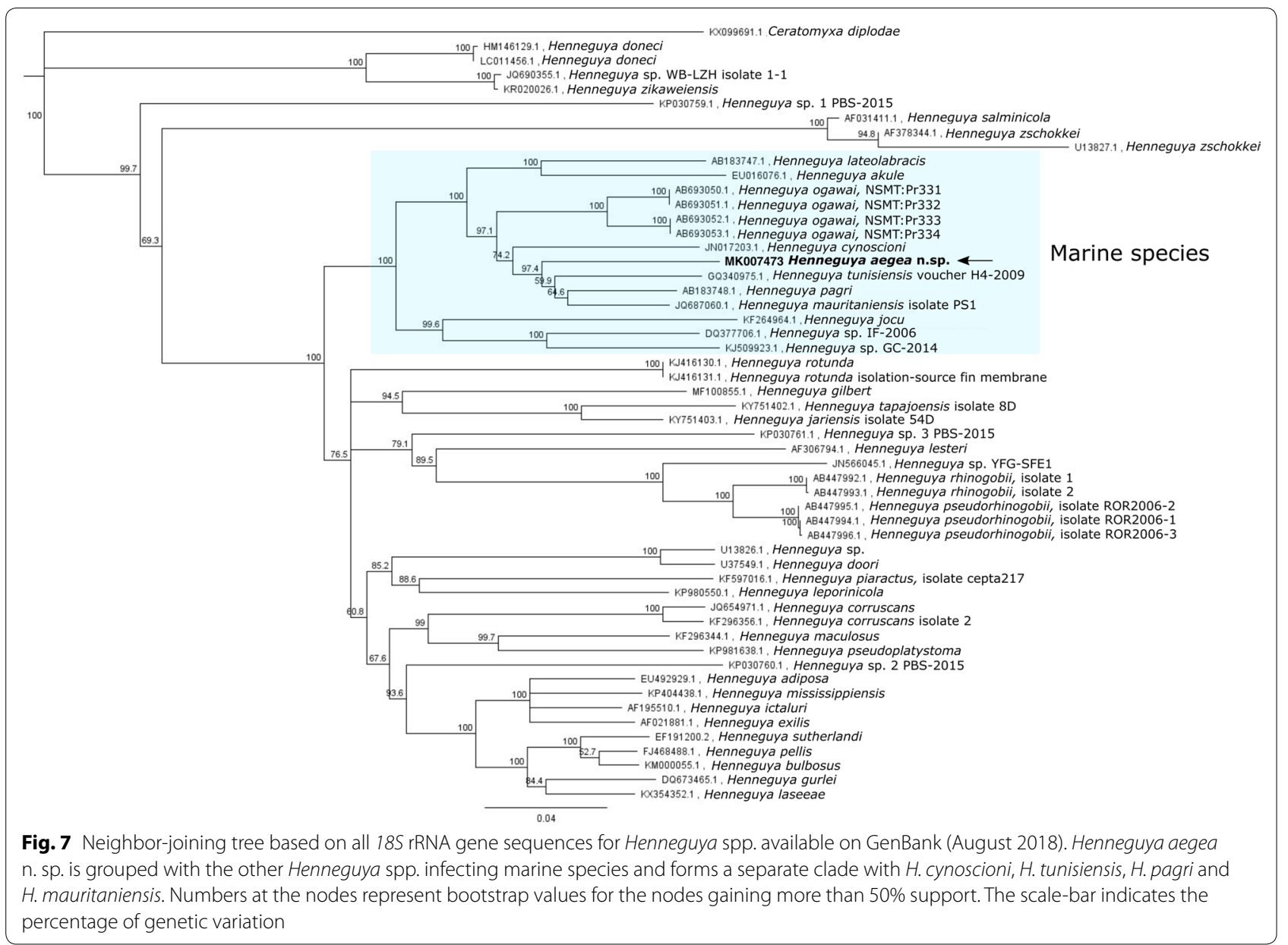

H. ouakamensis Kpatcha, Faye, Diebakate, Fall \& Toguebaye, 1997, H. yoffensis Kpatcha, Faye, Diebakate, Fall \& Toguebaye, 1997, H. lateolabracis, H. pagri and H. akule; five Kudoa spp., and 18 Myxobolus spp. In addition to these, three other Henneguya spp. have been reported to infect hearts: $H$. mauritaniensis and $H$. cynoscioni from Pagrus caeruleostictus (Valenciennes) and Cynoscion nebulosus (Cuvier), respectively [22, 29] and one unidentified Henneguya sp. from the gilthead seabream [14]. The plasmodia of the majority of the heart-infecting Henneguya spp. are located exclusively in the bulbus arteriosus. The plasmodia of $H$. aegea n. sp. were found both in the bulbus arteriosus but also in the ventricle of its host which differentiates this species from the other described Henneguya spp. To our knowledge, the only other parasite of this genus that has its plasmodia in the ventricle is Myxobolus hearti Chen, 1998 from the Prussian carp, Carassius gibelio (Bloch) [28], which, however, does not have plasmodia in the bulbus arteriosus.

With the growing molecular data that have become available in recent years, we examined the phylogenetic position of the new species, using the $S S U$ rRNA gene as a phylogenetic marker against all sequences from congeneric species available on GenBank. In the phylogenetic tree, $H$. aegea n. sp. grouped with the other Henneguya spp. infecting marine species and formed a separate clade with $H$. cynoscioni, $H$. tunisiensis, $H$. pagri and $H$. mauritaniensis. The phylogeny obtained is in agreement with previously published analyses for Henneguya spp. [22, 30].

Based on morphology/morphometry data, tissue tropism and comparison with other available genetic sequences (molecular phylogenetic analysis), we concluded that the species isolated in the present study is a novel species, $H$. aegea $\mathrm{n}$. sp. One of the most interesting aspects of our study is related to the fact that the host, $P$. major is not native to the Mediterranean but rather introduced in the late 1980s [31]. This, together with the fact that myxobolid parasites are generally highly host-specific [32] suggests that the cultured $P$. major has contracted the parasite from a wild host, which remains unknown. It can be hypothesized that the original host is 
genetically close to $P$. major, more likely a member of the family Sparidae since myxobolid parasites usually infect a single host or a limited number of closely related hosts. The possibility that the novel parasite was brought to the Mediterranean Sea via the introduced host is highly unlikely. Only fertilized eggs of $P$. major were imported to Europe from Japan and thus $H$. aegea n. sp. could not be brought together since myxosporeans are not transmitted vertically. Generally, only a small fraction of the parasite species accompanies their host during its introduction to a new area [33]. Torchin et al. [33] suggested that "introduced populations are often derived from relatively small subsets of native populations (and sometimes from uninfected life-history stages), and this reduces the probability of introducing parasites along with a host species. Another potential limitation for the establishment of introduced parasites is that many parasites have complex life-cycles requiring more than one host". Both elements of this hypothesis are valid in this case since imported eggs can be seen as uninfected stages of the host and the life-cycle of Henneguya spp. involves an actinosporean alternative stage that develops in an oligochaete [34].

Despite the fact that the parasite was probably not introduced with the host, there is a clear risk that has emerged with the importation of $P$. major into the Mediterranean. If the native/local parasite is highly hostspecific and the introduced host is competent for that particular parasite, there is a tendency for amplification of the disease with a "spillback" onto native hosts [35]. These concepts, however, have been assessed and examined in respect to invasive or introduced host species that may interact freely in the new locality with native hosts. The situation in aquaculture differs significantly, since introduced fish species are confined in a limited space and may act as a reservoir for the parasites. An example comes from outbreaks of Kudoa amamiensis Egusa \& Nakajima, 1980 in farmed Japanese amberjacks, Seriola quinqueradiata Temminck \& Schlegel, introduced from northern to southern Japan, where amberjacks were assumed to be accidental hosts of the parasite that was found in several native wild fishes [36]. Future studies should focus on the identification of the natural hosts (fish and possible non-fish intermediate hosts) in the specific geographical location in order to evaluate the likelihood of the spillback hypothesis.

The spores of $H$. lateolabracis and $H$. pagri are the cause of lesions in the heart, spleen and gill tissues of the affected fish as already described by other authors [13, 37]. Arteriolosclerosis is common in the animal kingdom, as is the well-known atherosclerosis in humans, and is defined as a chronic arterial change with loss of elasticity and narrowing of the lumen by proliferation of the arterial wall with degeneration [38]. It differs from atherosclerosis lesions commonly seen in humans which is characterized by inflammation, fatty degeneration and mineralization of the vessel wall and is rather a degenerative disease. The narrowing of the vessel lamina by the intima proliferations can lead to tissue infarctions and degeneration of the surrounding tissue in any organ, especially under conditions of increased stress and activity. A similar result was found in a case of the Prussian carp infected with $M$. hearti [28]. Although arteriosclerosis in animals leads less often to infarction than atherosclerosis in humans, and is often regarded as a minor finding in animals, we believe that the severity of the lesions in the tissues examined with complete occlusion of the arterial lumen, might be the cause or a major contributor to the increased mortalities of the diseased fish.

Micro-CT technology provides fascinating insights regarding the morphology and the location of the plasmodia in a non-destructive way. The same samples can be later used for histology or dissection in order to confirm and further study the presence of the plasmodia as in this case or in other lesions. In our investigation, we have also noticed significant differences between the healthy and the infected hearts in regard to the density of the tissue (data not shown). In a following study, we intend to study these differences in combination with histopathology.

\section{Conclusions}

This study showed that even highly host-specific parasites may affect exotic species causing disease and morbidity. The novel myxobolid parasite, $H$. aegea n. sp. caused lesions in the blood vessels of cultured $P$. major which is an introduced species in the Mediterranean. The natural host of the parasite is not known; however, based on the host specificity of Henneguya spp. and the type of pathology observed, it is expected that the presence of a novel competent host raised in aquaculture at high densities could result in spillback of $H$. aegea $\mathrm{n}$. sp. to native fish host populations.

\section{Supplementary information}

Supplementary information accompanies this paper at https://doi. org/10.1186/s13071-020-3888-7.

Additional file 1: Video S1. 3D-video rendering of the two micro-CT scans of the two infected hearts showing, in different section planes, the internal location of spore-containing plasmodia (red arrows).

\section{Abbreviations}

18S rDNA: 18 S ribosomal deoxyribonucleic acid; SEM: scanning electron microscopy; H\&E: haematoxylin and eosin; Micro-CT: micro X-ray computed tomography; PTA: phosphotungstic acid; HCMR: Hellenic Centre for Marine Research; MP: megapixels; CCD: charged coupled device; PCR: polymerase chain reaction; SD: standard deviation. 


\section{Acknowledgements}

The authors are thankful to Professor Lloyd Vaughan, Veterinary Pathology, Vetsuisse Faculty, University of Zürich, for critically reviewing the manuscript and Mr. Nektarios Platis for help in the fish farm.

\section{Authors' contributions}

PK design the study, performed the microscopy (light and SEM), analyzed the data and drafted the manuscript. PV performed the sampling of the fish, diagnosed the disease and drafted the manuscript. KK analyzed the samples with micro-CT and drafted the manuscript. MR analyzed the histopathology. JS and MA analyzed the data and drafted the manuscript. MCC analyzed the micro-CT data. MIT analyzed histology data. CK performed the molecular work. All authors read and approved the final manuscript.

\section{Funding}

We acknowledge support of this study by the project "MOdern UNifying Trends in marine biology - MOUNT" (MIS 5002470), which is implemented under the "Action for the Strategic Development on the Research and Technological Sector", funded by the Operational Programme "Competitiveness, Entrepreneurship and Innovation" (NSRF 2014-2020) and co-financed by Greece and the European Union (European Regional Development Fund).

\section{Availability of data and materials}

Data supporting the conclusions of this article are included within the article. The type-material was deposited in the Museum of Natural History of Crete under the accession number NHMC60.8. The newly generated sequence was deposited in the GenBank database under the accession number MK007473.

\section{Ethics approval and consent to participate}

The fish used in this study were obtained during non-experimental clinical veterinary practices which constitute standard production procedures for the fish farm. Fish sampling and handling was done by a licensed veterinarian. Special care for minimizing animal distress was given according to the EU legislation.

\section{Consent for publication}

Not applicable.

\section{Competing interests}

The authors declare that they have no competing interests.

\begin{abstract}
Author details
1 Institute of Marine Biology, Biotechnology and Aquaculture, Hellenic Centre for Marine Research, Gournes, Heraklion, Greece. ${ }^{2}$ Vetcare, Dimitressa Street, 11528 Athens, Greece. ${ }^{3}$ PathoVet AG, Buckstreet 2, CH-8317 Tagelswangen, Switzerland. ${ }^{4}$ Department of Biology, University of Crete, 70013 Heraklion, Greece. ${ }^{5}$ Scottish Association for Marine Science, University of Highlands and Islands, Oban PA37 1QA, UK.
\end{abstract}

Received: 21 May 2019 Accepted: 4 January 2020

Published online: 14 January 2020

\section{References}

1. Kentouri M, Papandroulakis N, Pavlidis M, Divanach P. Culture of the red porgy, Pagrus pagrus, in Crete. Present knowledge, problems and perspectives. Zaragoza. 1995;16:65-78.

2. Rotllant J, Tort L, Montero D, Pavlidis M, Martinez M, Wendelaar Bonga SE, et al. Background colour influence on the stress response in cultured red porgy Pagrus pagrus. Aquaculture. 2003;223:129-39.

3. Pavlidis M, Karkana M, Fanouraki E, Papandroulakis N. Environmental control of skin colour in the red porgy, Pagrus pagrus. Aquac Res. 2008;39:837-49.

4. Dulcic J, Kraljevic M. On the record of red seabream Pagrus major (Temminck and Schlegel, 1843) (Osteichthyes: Sparidae) in the Adriatic Sea. Sci Mar. 2007;71:15-7.

5. Kent ML. Marine netpen farming leads to infections with some unusual parasites. Int J Parasitol. 2000;30:321-6.
6. Kent ML, Andree KB, Bartholomew JL, El-Matbouli M, Desser SS, Devlin $\mathrm{RH}$, et al. Recent advances in our knowledge of the Myxozoa. J Eukaryot Microbiol. 2001;48:395-413.

7. Rigos G, Katharios P. Pathological obstacles of newly-introduced fish species in Mediterranean mariculture: a review. Rev Fish Biol Fish. 2010;20:47-70.

8. Diamant A. Fish-to-fish transmission of a marine myxosporean. Dis Aquat Organ. 1997;30:99-105.

9. Katharios P, Kokkari C, Sterioti A, Smyrli M, Kalatzis PG. Enteromyxum leei infection in parrotfish, Sparisoma cretense: histopathological, morphological and molecular study. Vet Parasitol. 2013;199:136-43.

10. Sitjà-Bobadilla A, Alvarez-Pellitero P. Sphaerospora testicularis sp. nov. (Myxosporea: Sphaerosporidae) in wild and cultured sea bass, Dicentrarchus labrax (L.), from the Spanish Mediterranean area. J Fish Dis. 1990;13:193-203.

11. Eiras JC. Synopsis of the species of Ceratomyxa Thélohan, 1892 (Myxozoa: Myxosporea: Ceratomyxidae). Syst Parasitol. 2002;52:43-54.

12. Eiras JC, Adriano EA. A checklist of new species of Henneguya Thélohan, 1892 (Myxozoa: Myxosporea, Myxobolidae) described between 2002 and 2012. Syst Parasitol. 2012;83:95-104.

13. Yokoyama H, Itoh N, Tanaka S. Henneguya pagri n. sp. (Myxozoa: Myxosporea) causing cardiac henneguyosis in red sea bream, Pagrus major (Temminck \& Schlegel). J Fish Dis. 2005;28:479-87.

14. Caffara M, Marcer F, Florio D, Quaglio F, Fioravanti ML. Heart infection due to Henneguya sp. (Myxozoa, Myxosporea) in gilthead sea bream (Sparus aurata) cultured in Italy. Bull Eur Assoc Fish Pathol. 2003;23:108-12.

15. Bahri S, Hassine OKB, Marques A. Henneguya sp. (Myxosporea, Bivalvulida) infecting the gills of wild gilthead sea bream Sparus aurata L., from the coast of Tunisia. Bull Eur Assoc Fish Pathol. 1996;16:51-3.

16. Lom J, Arthur JR. A guideline for the preparation of species descriptions in Myxosporea. J Fish Dis. 1989;12:151-6.

17. Bennett HS, Wyrick AD, Lee SW, McNeil JH. Science and art in preparing tissues embedded in plastic for light microscopy, with special reference to glycol methacrylate, glass knives and simple stains. Stain Technol. 1976:51:71-97.

18. Metscher BD. MicroCT for comparative morphology: simple staining methods allow high-contrast 3D imaging of diverse non-mineralized animal tissues. BMC Physiol. 2009;9:11.

19. Fiala I. The phylogeny of Myxosporea (Myxozoa) based on small subunit ribosomal RNA gene analysis. Int J Parasitol. 2006;36:1521-34.

20. Whipps CM, Adlard RD, Bryant MS, Lester RJG, Findlav V, Kent ML. First report of three Kudoa species from eastern Australia: Kudoa thyrsites from mahi mahi (Coryphaena hippurus), Kudoa amamiensis and Kudoa minithyrsites n. sp. from sweeper (Pempheris ypsilychnus). J Eukaryot Microbiol. 2003;50:215-9.

21. Kumar S, Stecher G, Tamura K. MEGA7: Molecular Evolutionary Genetics Analysis version 7.0 for bigger datasets. Mol Biol Evol. 2016;33:1870-4.

22. Dyková I, de Buron I, Roumillat WA, Fiala I. Henneguya cynoscioni sp. n. (Myxosporea: Bivalvulida), an agent of severe cardiac lesions in the spotted seatrout, Cynoscion nebulosus (Teleostei: Sciaenidae). Folia Parasitol (Praha). 2011:58:169-77.

23. ICZN International Commission on Zoological Nomenclature. Amendment of articles 8, 9, 10, 21 and 78 of the International Code of Zoological Nomenclature to expand and refine methods of publication. Bull Zool Nomencl. 2012;69:161-9.

24. Liu Y, Whipps CM, Gu ZM, Zeng LB. Myxobolus turpisrotundus (Myxosporea: Bivalvulida) spores with caudal appendages: investigating the validity of the genus Henneguya with morphological and molecular evidence. Parasitol Res. 2010;107:699-706.

25. Bahri S, Andree KB, Hedrick RP. Morphological and phylogenetic studies of marine Myxobolus spp. from mullet in Ichkeul Lake, Tunisia. J Eukaryot Microbiol. 2003;50:463-70.

26. Bahri S, Marton S, Marques A, Eszterbauer E. Henneguya tunisiensis n. sp. (Myxosporea: Bivalvulida), a new gill parasite of Symphodus tinca (L.) (Teleostei: Labridae) off Tunisia. Syst Parasitol. 2010;76:93-101.

27. Molnár K. Site preference of fish myxosporeans in the gill. Dis Aquat Organ. 2002;48:197-207.

28. Ye L, Li W, Wang W, Wu S, Wang G. Updated morphology, histopathology and molecular phylogeny of Myxobolus hearti, cardiac myxosporea in gibel carp, Carassius gibelio (Bloch). J Fish Dis. 2014;37:11-20. 
29. Khlifa S, Miller TL, Adlard RD, Faye N, Sasal P. Henneguya mauritaniensis n. sp. (Myxozoa) from the arterial bulb of Pagrus caeruleostictus (Valenciennes, 1830) off Mauritania. Parasitol Res. 2012;111:1287-94.

30. Carriero MM, Adriano EA, Silva MRM, Ceccarelli PS, Maia AAM. Molecular phylogeny of the Myxobolus and Henneguya genera with several new South American species. PLoS ONE. 2013;8:e73713.

31. Sweetman JW. Larviculture of Mediterranean marine fish species: current status and future trends. J World Aquac Soc. 1992;23:330-7.

32. Molnár K. Comments on the host, organ and tissue specificity of fish myxosporeans and on the types of their intrapiscine development. Parasitol Hung. 1994;27:5-20.

33. Torchin ME, Lafferty KD, Dobson AP, McKenzie VJ, Kuris AM. Introduced species and their missing parasites. Nature. 2003;421:628-30.

34. Kallert DM, Eszterbauer E, El-Matbouli M, Erséus C, Haas W. The life cycle of Henneguya nuesslini Schuberg \& Schröder, 1905 (Myxozoa) involves a triactinomyxon-type actinospore. J Fish Dis. 2005;28:71-9.

35. Young HS, Parker IM, Gilbert GS, Sofia Guerra A, Nunn CL. Introduced species, disease ecology, and biodiversity-disease relationships. Trends Ecol Evol. 2017;32:41-54.

36. Egusa S, Nakajima K. Kudoa amamiensis n. sp. (Myxosporea: Multivalvulida) found in cultured yellowtails and wild damselfishes from AmamiOhshima and Okinawa, Japan. Bull Jpn Soc Sci Fish. 1980;46:1193-8.

37. Yokoyama H, Kawakami H, Yasuda H, Tanaka S. Henneguya lateolabracis sp. n. (Myxozoa: Myxosporea), the causative agent of cardiac henneguyosis in Chinese sea bass Lateolabrax sp. Fish Sci. 2003;69:1116-20.
38. Maxie G. Jubb, Kennedy \& Palmer's pathology of domestic animals: 3-volume set. St. Luis: Elsevier; 2015.

39. Work TM, Takata G, Whipps CM, Kent ML. A new species of Henneguya (Myxozoa) in the big-eyed scad (Selar crumenophthalmus) from Hawaii. J Parasitol. 2008;94:524-9.

40. Moser M, Love MS. Henneguya sebasta sp. n. (Protozoa, Myxosporida) from California rockfish, Sebastes spp. J Parasitol. 1975:61:481-3.

41. Laird M. Henneguya vitiensis n sp., a myxosporidian from a Fijian marine fish, Leiognathus fasciatus (Lacépède, 1803). J Parasitol. 1950;36:285-92.

42. Ganapati PN. On a new myxosporidian Henneguya otolithi n. sp. a tissue parasite from the bulbus arteriosus of two species of fish of the genus Otolithus. Proc Plant Sci. 1941;13:135-50.

43. Li YC, Sato H, Kamata Y, Ohnishi T, Sugita-Konishi Y. Three novel myxobolid species of genera Henneguya and Myxobolus (Myxosporea: Bivalvulida) from marine fish in Japan. Parasitol Res. 2012;111:819-26.

44. Zhang J, Mo X, Li N, Chen W, Yang C. Supplementary description of Henneguya zikawiensis Sikama, 1938 and its molecular phylogeny. J Neijiang Norm Univ. 2015;35:42-6.

\section{Publisher's Note}

Springer Nature remains neutral with regard to jurisdictional claims in published maps and institutional affiliations.
Ready to submit your research? Choose BMC and benefit from:

- fast, convenient online submission

- thorough peer review by experienced researchers in your field

- rapid publication on acceptance

- support for research data, including large and complex data types

- gold Open Access which fosters wider collaboration and increased citations

- maximum visibility for your research: over $100 \mathrm{M}$ website views per year

At BMC, research is always in progress.

Learn more biomedcentral.com/submissions 